\title{
PHYSIOLOGICAL AND MOLECULAR CHARACTERIZATION OF DROUGHT RESPONSES AND SCREENING OF DROUGHT TOLERANT RICE VARIETIES
}

\author{
CARACTERIZAÇÃO FISIOLÓGICA, MOLECULAR E SELEÇÃO DA RESPOSTA A \\ TOLERÂNCIA À SECA EM VARIEDADES DE ARROZ
}

\author{
Loo Lean FEN ${ }^{1}$; Mohd Razi ISMAIL ${ }^{1}$; B. ZULKARAMI ${ }^{1}$; \\ Mohammad SHUKRI Abdul RAHMAN ${ }^{1}$; M. Robiul ISLAM ${ }^{1,2}$
}

1. Laboratory of Food Crops, Institute of Tropical Agriculture Universiti Putra Malaysia, Serdang 43400, Selangor, Malaysia; 2. Department of Agronomy and Agricultural Extension, Rajshahi University, Rajshahi 6205, Bangladesh. razi@putra.upm.edu.my

\begin{abstract}
Drought stress has now become a severe threat to ensure food security in the developing world as well as in Malaysia. To dertermine physiological and molecular determinants of drought stress and screening of drought tolerant rice varieties, an experiment was conducted in a greenhouse at Universiti Putra Malaysia using eleven rice varieties and two irrigation regimes (well irrigated and water stressed). The present study indicated that traditional rice variety Puteh Perak and Siam is superior drought tolerant while IRRI 2011- IRLON Plot no: 064, MR 220 and BRRI Dhan 56 are moderately drought tolerant, and IRRI 2011- IRLON Plot no: 050 and MR 84 are drought sensitive rice variety. Drought tolerance of those varieties were measured based on rate of tiller reduction, leaf rolling score and drought score during water stress condition. Leaf rolling score was positively correlated to drought score, chlorophyll content and proline accumulation. Significant increase in the proline accumulation and antioxidant enzyme activities (peroxidase and catalase) were also observed under drought stress in all the rice varieties except Siam and Puteh Perak. All the rice varieties including drought tolerant and sensitive showed the existence of OsLEA 30 genes.
\end{abstract}

KEYWORDS: Drought stress. Leaf rolling score. Drought score. Oryza sativa L.. OsLEA 30 gene

\section{INTRODUCTION}

Rice (Oryza sativa L.) is one of the three major food crops of the world. Being grown world wide, it is the staple food for more than half of the world's population. It is a nutritious cereal crop, provides $20 \%$ calories and $15 \%$ protein requirements of world population. Besides being the cheapest source of carbohydrate and protein in Asia, it is also a source of minerals and fibre. Rice straw and bran are important animal feed in many countries. About $92 \%$ of the world's rice is produced and consumed in Asia. A majour part of asian rice grown under flooded irrigation and water is the main limiting factor for increased production of rice (AKINBILE et al., 2011).

The lower productivity of Asian rice in most of the cases is attributed to various abiotic stresses including drought. Drought is defined as water stress mainly due to lack of rain during crop growing period. Shortage of water is the main obstacle for rice production in rainfed ecosystems since most of the rice varieties are susceptible to water stress (MOSTAJERAN; RAHIMI-EICHI, 2009). Drought stress has now become a severe threat to ensure food security in the developing world including Malaysia. Although water is required all over the growth periods of rice plants, there are some critical growth stages when drought stress impacts seriously and create a massive reduction in quality and quantity of yield (ISLAM et al., 2011). The effect of drought on agriculture is extensive as it limiting crop growth and yield. Other than that, drought stress also involved with many biochemical, molecular, and physiological changes that influence various cellular and whole plant processes and reduce quality and quantity of yield (PRASAD; STAGGENBORG, 2008). Crop responses to drought stress and its tollerence level can be measured by monitoring different phytophysiological changes at increasing drought period (ISLAM et al. 2011).

Developing rice plants resistance to drought is one of the famous methods to increase crop productivity (XOCONOSTLE-CAZARES et al., 2010). Nevertheless, this approach requires an understanding of physiological mechanisms at different developmental stage and duration of drought period. Hence, the aim of the present study is screening of drought tolerant rice varieties and to evaluate morphological, physiological, biochemical and molecular aspects of stress tolerance in different varieties of rice.

\section{MATERIAL AND METHODS}

Plant materials and growth condition 
This study was conducted in a greenhouse at Universiti Putra Malaysia using eleven rice varieties (Oryza sativa cv. MR4, MR9, MR84, MR219, MR220, Dular, Siam, Puteh Perak, BRRI Dhan 56, IRRI 2011-IRLON Plot No: 50 and IRRI 2011IRLON Plot No: 64) collected from Gene bank MARDI Research Station, Malaysia and Bangladesh Rice Research Institute (BRRI), Bangladesh. Pregerminated seeds of each variety were grown in a pot containing clay loom soil. Water stress was imposed by withholding irrigation at 21 days after sowing. Water level in well watered treatment (control) was maintained at $5 \mathrm{~cm}$ above the surface of the soil. The experiment was arranged with completely randomized design (CRD) with three replications.

\section{Soil moisture measurement}

Soil moisture was measured by using soil moisture meter $(\mathrm{HH} 2)$ at $3,6,9,12$ and 15 days after stress.

\section{Chlorophyll content (SPAD value)}

Chlorophyll content of leaf was determined by using SPAD meter at 11 days after stress.

\section{Leaf rolling score}

Leaf rolling was recorded mid-day at 15 days after stress using the scale describe in Figure 1, according to O'Toole and Cruz, 1979.

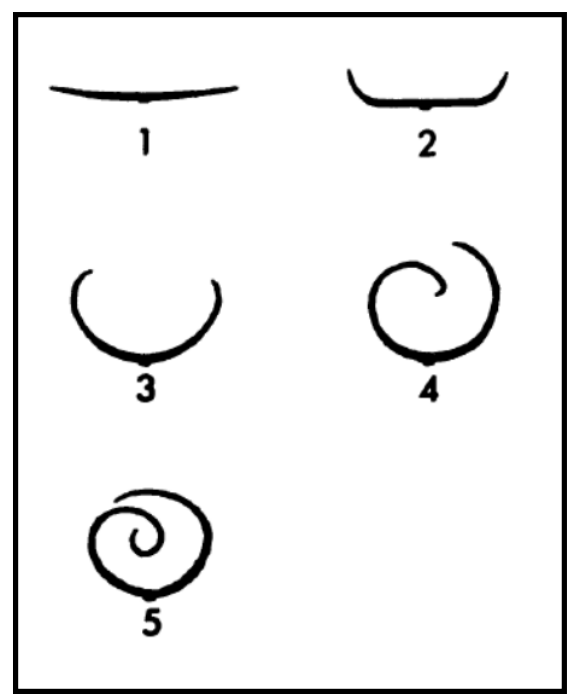

Figure 1. Flat (1) and tightly rolled (5) leaf and their rolling score.

\section{Drought score}

Data's were taken on 15 days after drought imposed and drought score was observed visually using scale according to De Datta et al. (1988) as mentioned in the Table 1.

Table 1. Leaf symptoms and corresponding drought score according to De Datta et al. (1988)

\begin{tabular}{cl}
\hline Drought score & Description \\
\hline 1 & No symptoms of stress effects \\
2 & Slight tip drying \\
4 & Tip drying extended to $1 / 4$ length in $25 \%$ of all leaves (normally the older leaves) \\
5 & Tip drying extended to $1 / 4$ length in at most $50 \%$ of all leaves \\
& Tip drying extended to $1 / 4$ length or more in $50 \%$ of all leaves with $25 \%$ of leaves \\
6 & fully dried \\
7 & Mo\% of all leaves fully dried \\
8 & 70\% of all leaves fully dried \\
10 & More than $70 \%$ of all leaves fully dried \\
\hline
\end{tabular}




\section{Proline determination}

Free proline content was estimated following the procedure described by BATES et al. (1973). Youngest fully expanded leaves was frozen in the liquid nitrogen and stored in a refrigerator at $70^{\circ} \mathrm{C} .0 .5 \mathrm{~g}$ of frozen sample was ground with liquid nitrogen using pestle and mortar and homogenized with $10 \mathrm{ml}$ of sulfosalicylic acid (3\%). The homogenate was filtered using filter paper. $2 \mathrm{ml}$ of the filtrate was added with $2 \mathrm{ml}$ of glacial acetic acid and $2 \mathrm{ml}$ acid ninhydrin in a test tube for one hour in a water bath at $95^{\circ} \mathrm{C}$. The reaction mixture was then cooled in an ice bath for 10-15 minutes. After that, $4 \mathrm{ml}$ of toluene was added to the reaction mixture and mixed vigorously with a test tube stirrer for 20 seconds. Supernatant layer was put into a quartz cuvette and measured at $520 \mathrm{~nm}$ using spectrophotometer to get the absorbance data. Toluene was used as blank. Proline standard curve was used to determine the concentration of proline in the samples.

\section{Peroxidase determination}

Enzyme extraction was determined using the procedure derived by Aebi (1984). $0.5 \mathrm{~g}$ of frozen leaf sample was crushed to a fine powder with the present of liquid nitrogen. The mixture was then centrifuged at $10,000 \mathrm{~g}$ for 10 minutes at $4^{\circ} \mathrm{C}$. The supernatant was placed into a $2.5 \mathrm{ml}$ centrifuge tube. Enzyme extraction was stored in a refrigerator at $-80^{\circ} \mathrm{C}$ for long term uses. For peroxidase measurement, $1.8 \mathrm{ml}$ of reaction mixture and $200 \mu \mathrm{l}$ distilled water as a blank was placed in a quartz cuvette. $1200 \mu \mathrm{l}$ of $71.4 \mathrm{mM}$ potassium phosphate buffer, $200 \mu \mathrm{l}$ of $1 \mathrm{mM}$ EDTA, $200 \mu \mathrm{l}$ of $1 \mathrm{mM}$ $\mathrm{H}_{2} \mathrm{O}_{2}$ and $200 \mu \mathrm{l}$ of $1 \mathrm{mM}$ guaiacol were added into the cuvette for sample measurement. The reaction was started by added $200 \mu \mathrm{l}$ of enzyme extraction at $420 \mathrm{~nm}$ for 30 seconds using spectrophotometer to get the absorbance data. Protein absorbance of each sample was measured by $40 \mu 1$ of enzyme extraction and $2 \mathrm{ml}$ of Bradford reagent at $595 \mathrm{~nm}$ using spectrophotometer. Protein standard curve was used to determine the concentration of peroxidase in the samples.

\section{Catalase determination}

Catalase activity (CAT) was measured with modified procedure of AEBI (1983). 120 $\mu$ l enzyme extract was added to reaction mixture consisted $2.8 \mathrm{ml}$ of $50 \mathrm{mM}$ phosphate buffer $(\mathrm{pH}=7.0)$ and $80 \mu \mathrm{l}$ of $\mathrm{H}_{2} \mathrm{O}_{2}$. Catalase activity was determined by measuring the increase in absorbance of $\mathrm{H}_{2} \mathrm{O}_{2}$ during $1 \mathrm{~min}$ at $240 \mathrm{~nm}$ in a spectrophotometer with $3 \mathrm{ml}$ of total reaction mixture. CAT activity was expressed as change in absorbance by mmolmin ${ }^{-}$ ${ }^{1} \mathrm{mg}^{-1}$ protein.

\section{Detection of OsLEA30 genes}

Plant material and RNA isolation: Fresh leaf samples were used for genomic RNA extraction and the RNA isolation was done with The NucleoSpin ${ }^{\circledR}$ RNA/Protein kit. 0.1g of leaf sample was homogenized carefully with mortar and pestle in presence of liquid nitrogen. Cell lysis began when the extraction transferred to a test tube containing $350 \mu 1$ Buffer PL2 and 3.5 $\mu 1 \beta$-mercaptoethanol. The mixture was vortex thoroughly. Lysate was filtrated through violet ring (NucleoSpin ${ }^{\circledR}$ Filter) and centrifuged for $1 \mathrm{~min}$ at $11,000 \mathrm{~g}$. The violet ring was dissolved with $350 \mu$ l ethanol (70\%) and added into the homogenized lysate. The sample was loaded into NucleoSpin ${ }^{\circledR}$ RNA/ Protein Column (light blue ring) and centrifuged for $30 \mathrm{~s}$ at $11,000 \mathrm{~g}$. $350 \mu \mathrm{l}$ MDB was added to the sample and centrifuged at $11,000 \mathrm{~g}$ for $1 \mathrm{~min}$ to dry the membrane. $95 \mu \mathrm{l}$ rDNase reaction mixture was applied directly onto the center of the silica membrane of the column and incubated at room temperature for $15 \mathrm{~min}$. First wash was done by added $200 \mu \mathrm{l}$ Buffer RA2 to the light blue ring and centrifuged for $30 \mathrm{~s}$ at $11,000 \mathrm{~g}$. The light blue ring was placed into a new collection tube. During second wash, $600 \mu 1$ of Buffer RA3 was added to the light blue ring and centrifuged for $30 \mathrm{~s}$ at $11,000 \mathrm{~g}$. The flow through was discarded. $250 \mu 1$ Buffer RA3 was added at the third wash. The mixture was centrifuged for $2 \mathrm{~min}$ at $11,000 \mathrm{~g}$ in order to dry the silica membrane completely. The light blue ring was placed into a new RNase-free collection tube. The RNA was eluted in $60 \mu 1$ RNase-free $\mathrm{H}_{2} \mathrm{O}_{2}$ and centrifuged for $1 \mathrm{~min}$ at $11,000 \mathrm{~g}$. The nucleic acid concentration and purity of nucleic acid samples were measured by using NanoDrop 1000 Spectrophotometer.

sqRT-PCR amplification: The RNA samples were used directly for sqRT-PCR with OsLEA30 primers (Wang et al., 2007). The sqRTPCR amplification was performed in a volume of $20 \mu$ c containing $10 \mu \mathrm{l}$ of KAPA SYBR ${ }^{\circledR}$ FAST qPCR Master Mix (2X), $0.2 \mu \mathrm{l}$ of $0.2 \mu \mathrm{M}$ of OsLEA 30 forward and $O S L E A 30$ reverse primer, $0.5 \mu 1$ of dUTP and KAPA RT Mix (50X), $4 \mu$ of RNA template and $4.6 \mu$ l of nuclease-free water. The step of cDNA synthesis was run together with conventional PCR amplification where the initial step of $42^{\circ} \mathrm{C}$ for $15 \mathrm{~min}$ was cDNA synthesis. The following step was inactivate RT which was set at $95^{\circ} \mathrm{C}$ for $5 \mathrm{~min}$. The conventional PCR amplification was $95^{\circ} \mathrm{C}$ for $5 \mathrm{~min}$, followed by 32 
cycles of $95^{\circ} \mathrm{C}$ for $30 \mathrm{~s}, 59^{\circ} \mathrm{C}$ for $30 \mathrm{~s}$ and $72^{\circ} \mathrm{C}$ for $1 \mathrm{~min}$ and 1 cycle of $5 \mathrm{~min}$ at $72^{\circ} \mathrm{C}$ for the final extension.

\section{Agarose gel electrophoresis of PCR products}

Amplified PCR product was analyzed by $1.5 \%$ agarose gel electrophoresis. About $0.375 \mathrm{~g}$ of agarose was melted in $25 \mathrm{ml}$ of $1 \mathrm{X}$ TBE buffer. The gel mixture was poured into a gel tray with comb at one end. After solidification, the agarose gel was removed carefully and kept in gel electrophoresis unit containing $1 \mathrm{X}$ TBE running buffer. 20 $\mu$ l of PCR product was loaded into the wells. The electrophoresis was carried out at 75 volt for about 40 minutes.
When ANOVA showed significant treatment and variety effects, the Least significant Difference (LSD) range test was applied to compare the means at $\mathrm{P}<0.05$.

\section{RESULTS}

Soil moisture content: Soil moisture in well watered condition was always higher than water stress condition as shown in Figure 2. Soil moisture in well watered condition was maintained at about $90 \%$ volumetric throughout the period of treatment imposed while soil moisture in water stress treatment decrease from $90 \%$ to $10 \%$ at 15 days after withholding water.

\section{Statistical analysis}

All data were analyzed using SAS software. Each treatment was analyzed in three replications.

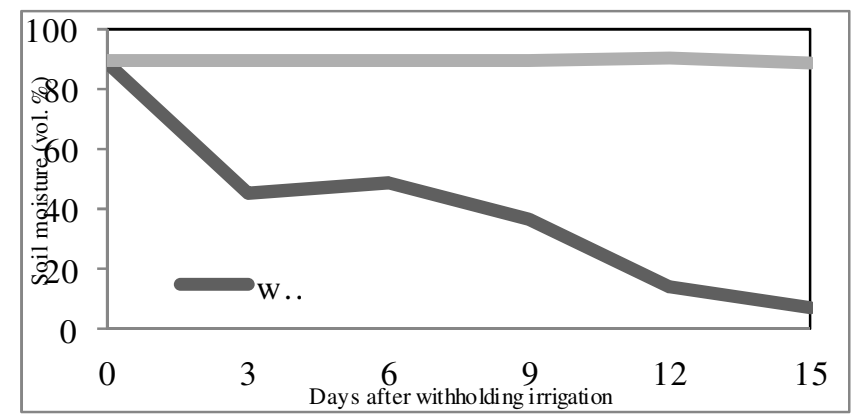

Figure 2. Soil moisture contents under well watered and water stress condition

\section{Leaf rolling score}

Water stress significantly affected the leaf movement of rice. Response of leaf rolling score to soil water stress was shown in Figure 3. According to this experiment, Puteh Perak obtained the lowest leaf rolling score among the varieties while MR 219, Dular and IRRI 2011- IRLON Plot no: 050 showed the highest leaf rolling score. Significant differences were noted between the varieties and leaf rolling score under water stress treatment. Leaf rolling score was positively correlated with drought score $(r=0.82162)$, chlorophyll content $(r=0.24426)$ and proline activity ( $\mathrm{r}=0.93852)$ (Table 4$)$.

\section{Drought score}

Water stress significantly increased leaf drying and increased drought score as describe in Figure 3. Significant differences were obtained between variety and drought score during water stress condition. MR 84, MR 220 and IRRI 2011IRLON Plot no: 064 showed the lowest drought score while IRRI 2011- IRLON Plot no: 050 showed the highest. Drought score was positively correlated with chlorophyll content $(r=0.28539)$ and proline activity $(\mathrm{r}=0.85520)$ as shown in Table 4.

\section{Number of tiller per plant}

Number of tiller per plant under water stress was found significantly lower than control (Table 2). MR 4 showed the highest number of tiller per plant while Siam obtained the lowest number of tiller during well watered treatment (control). MR 4, MR 220, MR84 and IRRI 2011- IRLON Plot no: 050 recorded higher number of tiller per plant during water stress. Number of tiller per plant was negatively correlated with leaf rolling score $(r=-$ $0.44778)$, drought score $(\mathrm{r}=-0.49797)$ and proline activity $(\mathrm{r}=-0.45311)$ as shown in Table 4. 


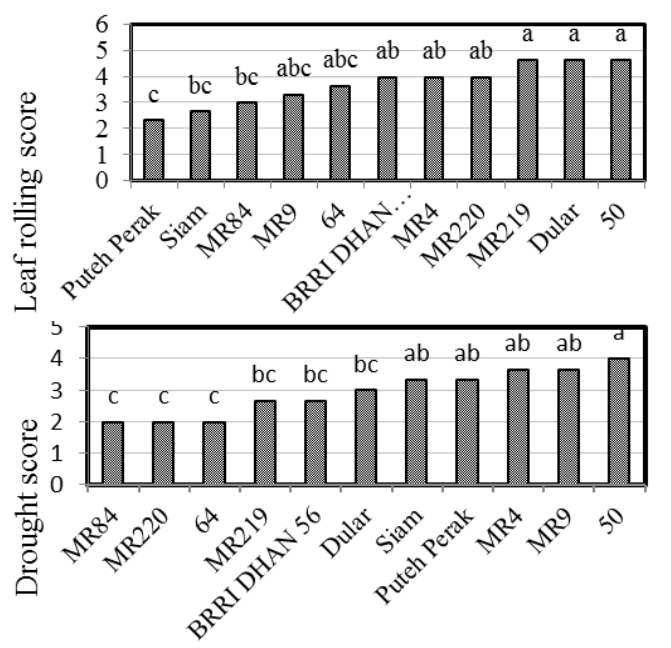

Figure 3. Leaf rolling score and drought score of eleven rice varieties during water stress; bars with different letters indicate significant differences $(\mathrm{P}<0.05)$ according to Least Significant Difference test.

Table 2. Number of tiller per plant and chlorophyll contents in rice varieties under well watered and water stressed condition.

\begin{tabular}{|c|c|c|c|c|}
\hline \multirow[t]{2}{*}{ Varieties } & \multicolumn{2}{|c|}{ Number of tiller per plant } & \multicolumn{2}{|c|}{$\begin{array}{l}\text { Chlorophyll content } \\
\text { (SPAD value) }\end{array}$} \\
\hline & Well watered & Water stressed & Well watered & Water stressed \\
\hline MR 4 & $20.00 \mathrm{a}$ & $9.33 \mathrm{a}$ & $43.50 \mathrm{a}$ & $44.20 \mathrm{a}$ \\
\hline MR 9 & $11.33 \mathrm{~cd}$ & $7.33 \mathrm{ab}$ & $35.56 \mathrm{bc}$ & $38.56 \mathrm{ab}$ \\
\hline MR 84 & $16.66 \mathrm{ab}$ & $8.00 \mathrm{a}$ & $40.13 \mathrm{ab}$ & $42.36 \mathrm{a}$ \\
\hline MR 219 & $13.33 \mathrm{bc}$ & $6.66 \mathrm{ab}$ & $36.33 \mathrm{bc}$ & $41.53 \mathrm{ab}$ \\
\hline MR 220 & $10.00 \mathrm{de}$ & $9.00 \mathrm{a}$ & $32.90 \mathrm{c}$ & $34.80 \mathrm{c}$ \\
\hline Dular & 8.33 ef & $4.66 \mathrm{bc}$ & $38.10 \mathrm{ab}$ & $36.16 \mathrm{bc}$ \\
\hline Siam & $5.00 \mathrm{~g}$ & $4.33 \mathrm{c}$ & $37.33 \mathrm{bc}$ & $42.40 \mathrm{a}$ \\
\hline Puteh Perak & $6.33 \mathrm{fg}$ & $4.66 \mathrm{bc}$ & $40.16 \mathrm{ab}$ & $40.10 \mathrm{ab}$ \\
\hline BRRI Dhan 56 & $10.33 \mathrm{de}$ & $7.33 \mathrm{ab}$ & $36.23 \mathrm{bc}$ & $40.26 \mathrm{ab}$ \\
\hline IRRI 2011- IRLON Plot no:050 & $15.00 \mathrm{bc}$ & $8.00 \mathrm{a}$ & $40.13 \mathrm{ab}$ & $43.33 \mathrm{a}$ \\
\hline IRRI 2011- IRLON Plot no:064 & $10.00 \mathrm{de}$ & $6.66 \mathrm{ab}$ & $37.40 \mathrm{bc}$ & $39.73 \mathrm{ab}$ \\
\hline Mean & 11.48 & 6.90 & 37.97 & 40.31 \\
\hline
\end{tabular}

Means with different letters within a column indicate significant differences $(\mathrm{P}<0.05)$ according to Least Significant Difference test

Table 4. The correlation coefficients of the experimental traits

\begin{tabular}{lcccccc}
\hline & Tiller & Lrs & Drs & Chl & Pro & POD \\
\hline Lrs & $-0.44778^{*}$ & & & & \\
Drs & $-0.49797^{*}$ & $0.82162^{*}$ & & & & \\
Chl & 0.06925 & $0.24426^{*}$ & $0.28539^{*}$ & & & \\
Pro & $-0.45311^{*}$ & $0.93852^{*}$ & $0.85520^{*}$ & 0.20715 & & \\
POD & 0.18298 & -0.10423 & 0.03579 & 0.21503 & 0.02499 & \\
CAT & 0.15899 & -0.07504 & -0.12080 & -0.17913 & -0.04018 & $0.40727^{*}$ \\
\hline
\end{tabular}


Chlorophyll content (SPAD value): All the varieties showed higher chlorophyll content during well-watered condition compared with water stress except Puteh Perak and Dular (Table 2). MR 4, MR 84, Siam and IRRI 2011- IRLON Plot no: 050 showed the highest chlorophyll content while MR 220 showed the lowest chlorophyll content during water stress. However, there was no significant difference between variety and chlorophyll contents were observed in both watering treatments.

Proline contents: The proline accumulation was higher under water stress condition compared with well watered condition in all the rice varieties (Table 3). Among the rice varieties, MR 219 showed the highest increase in proline accumulation (389.05\%), followed by MR 9, BRRI Dhan 56, IRRI 2011- IRLON Plot no: 050, MR 4, Dular, MR 220, MR 84, IRRI 2011- IRLON Plot no: 064, Puteh Perak and Siam. Puteh Perak showed the lowest value of proline activity during water stress.

\section{Peroxidase activity}

The peroxidase activities in leaves increased for water stress and MR 4 and MR 220 showed the higher peroxidase activity during well watered condition (Table 3). MR 84 showed the highest peroxidase activity during water stress condition while MR 219 showed the lowest. All the varieties showed higher peroxidase activity during water stress condition except Siam, MR 4, MR 219 and MR 220. These four varieties showed reduction in peroxidase activity compared to well-watered condition.

\section{Catalase activity}

The catalase activity was not affected by water supply treatments but it varied within the rice varieties (Table 3). MR 220 and IRRI 2011- IRLON Plot no: 050 were the only two varieties that showed significant difference under different irrigation treatments. Generally, catalase activity decrease during water stress. MR 220 and MR 9 showed higher catalase activity during well watered condition while MR 84 and MR 9 showed higher catalase activity under water stress.

\section{OsLEA 30 gene Detection}

The OsLEA 30 gene detection of selected rice varieties under water stress and well watered was shown in Figure 4. All the varieties included drought tolerant (BRRI Dhan 56) and sensitive (MR 84) variety showed the existence of OsLEA 30 gene in both water stress and well watered condition. The base pair of product was about 200 base pairs according to the Figure 4. 
FEN, L. L et al.

Table 3. Proline content, Peroxidase and catalase activity in rice varieties under well watered and water stressed condition.

\begin{tabular}{|c|c|c|c|c|c|c|}
\hline \multirow[t]{2}{*}{ Varieties } & \multicolumn{2}{|c|}{$\begin{array}{c}\text { Proline content } \\
\mathrm{Mg} / \mathrm{g} \mathrm{FW}\end{array}$} & \multicolumn{2}{|c|}{$\begin{array}{c}\text { Peroxidase activity } \\
\mu \mathrm{mol} / \mathrm{mg} \text { protein/sec }\end{array}$} & \multicolumn{2}{|c|}{$\begin{array}{c}\text { Catalase activity } \\
\mu \mathrm{mol} / \mathrm{mg} \text { protein } / \mathrm{min}\end{array}$} \\
\hline & Well watered & Water stressed & Well watered & Water stressed & Well watered & Water stressed \\
\hline MR 4 & $5.20 \mathrm{bc}$ & $22.01 \mathrm{a}$ & $10.00 \mathrm{a}$ & $8.37 \mathrm{ab}$ & $2278 \mathrm{bc}$ & $193 \mathrm{~cd}$ \\
\hline MR 9 & $4.78 \mathrm{~d}$ & $23.18 \mathrm{a}$ & $8.01 \mathrm{ab}$ & $8.67 \mathrm{ab}$ & $3244 \mathrm{a}$ & $276 a b$ \\
\hline MR 84 & $4.85 \mathrm{~cd}$ & $15.84 \mathrm{bc}$ & $8.47 \mathrm{ab}$ & $9.80 \mathrm{a}$ & $2875 \mathrm{ab}$ & $304 \mathrm{a}$ \\
\hline MR 219 & $4.78 \mathrm{~d}$ & $23.39 \mathrm{a}$ & $3.14 \mathrm{bc}$ & $2.30 \mathrm{c}$ & $777 \mathrm{e}$ & $107 \mathrm{ef}$ \\
\hline MR 220 & $4.86 \mathrm{~cd}$ & $19.67 \mathrm{ab}$ & $8.36 \mathrm{ab}$ & $3.99 \mathrm{bc}$ & $3404 \mathrm{a}$ & $256 \mathrm{ab}$ \\
\hline Siam & $5.92 \mathrm{a}$ & $12.06 \mathrm{c}$ & $5.91 \mathrm{ab}$ & $4.68 \mathrm{bc}$ & 1992 c & $222 \mathrm{bc}$ \\
\hline Puteh Perak & $5.31 \mathrm{bc}$ & $11.93 \mathrm{c}$ & $2.49 \mathrm{c}$ & $8.43 \mathrm{ab}$ & $1091 \mathrm{de}$ & $91 \mathrm{f}$ \\
\hline BRRI Dhan 56 & $4.96 \mathrm{~cd}$ & $22.44 \mathrm{a}$ & $4.97 \mathrm{ab}$ & $7.37 \mathrm{ab}$ & 2298 bc & $194 \mathrm{c} \mathrm{d}$ \\
\hline IRRI 2011- IRLON Plot no:050 & $4.88 \mathrm{~cd}$ & $20.96 \mathrm{a}$ & $5.48 \mathrm{ab}$ & $6.05 \mathrm{ab}$ & $1930 \mathrm{c}$ & $176 \mathrm{de}$ \\
\hline IRRI 2011- IRLON Plot no:064 & $5.09 \mathrm{~cd}$ & $16.13 \mathrm{~b} \mathrm{c}$ & $5.60 \mathrm{ab}$ & $8.62 \mathrm{ab}$ & $1665 \mathrm{~cd}$ & $206 \mathrm{~cd}$ \\
\hline Mean & 5.10 & 19.16 & 6.27 & 6.85 & 2161.3 & 207.9 \\
\hline
\end{tabular}

Means with different letters within a column indicate significant differences $(\mathrm{P}<0.05)$ according to Least Significant Difference test 


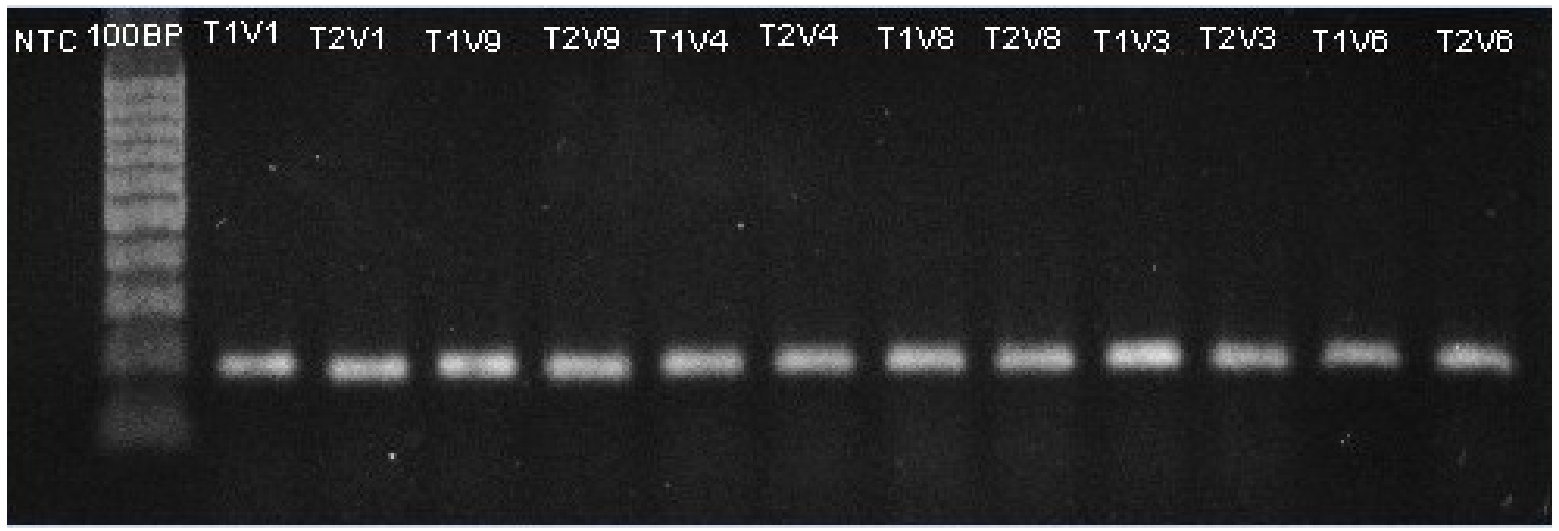

Figure 4. Detection of OsLEA 30 gene in selected rice varieties under both irrigation treatments by sqRT-PCR; NTC- Non template control; T1- water stress; T2- well watered; V1- MR4; V9- BRRI Dhan 56; V4MR219; V8- Puteh Perak; V3- MR84; V6- Dular

\section{DISCUSSION}

The sensitivity of rice varieties to water stress was noted during our experiment. MR 219, Dular and IRRI 2011- IRLON Plot no: 050 were the most sensitive variety to water stress while Puteh Perak was less sensitive. Leaf rolling score was positively correlated with drought score, chlorophyll content and proline accumulation. According to Chutia and Borah (2012), traditional rice varieties (such as Dular, Siam and Puteh Perak) had long and droopy leaves with larger leaf angle, are more susceptible to rolling due to their ability to conserved water in plant tissue. Reduction of transpiration rate by creating microclimate is one of the benefits of leaf rolling (KADIOGLU; TERZI, 2007; KADIOGLU et al., 2012). It has been reported that greater leaf rolling may be an important indicator linked to drought tolerance and may have a positive impact on crop yield under water stress conditions. Drought score is an alternative method to determine drought stress tolerance. Drought score of all the varieties were ranged between 2 to 4 , which indicates there nature as moderately resistant variety to drought stress. Siam, Puteh Perak, MR 4, MR 9 and IRRI 2011IRLON Plot no: 050 showed higher drought score, and this result was similar to the findings of Henderson et al., 1993, that the plants with higher leaf area or with a larger number of plants per pot showed higher drought score under water stress condition. The number of tiller per plant decreased with decreasing in soil moisture content. The number of tiller was also associated with leaf rolling score, drought score and proline accumulation. Drought stress reduce turgor pressure in the cell and therefore rusticated cell elongation and expansion which ultimately caused reduction in plant height, leaf area and crop growth (FAROOQ et al., 2009;). The closing of stomatal aperture and inhibition of photosynthesis during water stress declines internal carbon dioxide concentration. Drought tolerance varieties have the potentials to survive under such unfavourable condition. Therefore, lower production of tiller during water stress is also a determinant of drought tolerance since traditional low tillaring variety variety Siam and Puteh Perak showed higher tolerance to drought stress.

Proline contents in the leaf tissues increased significantly in all rice varieties except Siam and Puteh Perak (Table 3). Proline acts as an important osmolyte that widely produced by plants to stabilize membranes and maintain the conformation of proteins at low leaf water potentials. Free proline accumulation is related to drought tolerance. Many drought tolerant plant has high accumulation of proline (KADIOGLU; TERZI, 2007).

Antioxidant enzyme activities (Peroxidase and Catalase activity) were not affected either by watering treatments or rice variety. Puteh Perak was the only one variety, showed significantly increase in peroxidase activity during water stress while MR 220 and IRRI 2011- IRLON Plot no: 050 showed significantly decrease in peroxidase activity. Abedi and Pakniyat (2010) reported increased in peroxidase activity but decrease in catalase activity in oilseed rape. Increased in both enzyme activity during drought stress also reported in chickpea (MAFAKHERI et al., 2010), soybean (XUE et al., 2011) and rice. Decrease in peroxidase activity under severe drought stress may reflect the low ROS scavenging capacity and increased damage in cells (ABEDI; PAKNIYAT, 2010). Reduction of catalase activity is probably due to the inhibition of 
enzyme synthesis or change in the assembly of enzyme subunits under stress conditions (ABEDI; PAKNIYAT, 2010).

$L E A$ genes are a gene family plays important role in protection of water stress. OSLEA 30 gene is one of the members in $L E A$ gene family. According to Wang et al. (2007), OsLEA 30 gene usually expressed under normal condition. However, this gene was expressed in all the selected variety and thus conclusion on drought tolerance variety was not able to make from this result alone. This is due to the limitation of end point detection of reverse transcriptase PCR, which do not expressed the results as numbers. It is hard to differentiate between the different fold changes on the agarose gel. Hence, real time PCR is recommended for further experiments on similar study.
FEN, L. L et al.

The present study indicated Puteh Perak and Siam is superior drought tollarent, IRRI 2011IRLON Plot no: 064, MR 220 and BRRI Dhan 56 are moderately drought tolerant variety while IRRI 2011- IRLON Plot no: 050 and MR 84 were drought sensitive rice variety. Drought tolerant variety is selected based on rate of reduction of number of tiller, leaf rolling score and drought score. These traits may have greater relevance and benefit to future breeding program, particularly for screening drought tolerance at early stage.

\section{ANDACKNOWLEDGEMENT}

This research is supported by Long term Research Grant Scheme (LRGS), Food Security Project, Ministry of Higher Education, Malaysia.

RESUMO: Tolerância à seca tornou-se um importante tema da segurança alimentar nos países em desenvolvimento, bem como na Malásia. Com o objetivo de determinar os fatores fisiológicos e moleculares da tolerância à seca em variedades de arroz foi conduzido um experimento em casa de vegetação na Universidade Putra da Malásia usando 11 genótipos e dois sistemas de irrigação (vaso contendo plantas irrigadas e estressadas). O estudo mostrou que a variedade Puteh Perak e Siam foram superiores em condições de estresse hídrico, enquanto IRRI 2011-IRLON - PLOT 064 e MR 220 e BRRI Dhan 56 foram de tolerância moderada e IRRI 2011-IRLON 050 foram genótipos que apresentaram sensibilidade à seca. A tolerância à seca foi quantificada pela taxa de crescimento, nota visual para o enrolamento das folhas durante e nível de estresse durante o tempo de estresse hídrico. Enrolamento das folhas foi correlacionado com o nível de estresse hídrico, teor de clorofila e acúmulo de prolina. Aumento significativo no acúmulo de prolina e na atividade enzimática anti-oxidante (peroxidase e catalase) foram também observadas sobre estresse hídrico em todas as variedades de arroz tanto tolerantes quanto as sensíveis que esteve associado a existência de genes OsLEA 30.

PALAVRAS-CHAVE: Tolerância à seca. Enrolamento de folhas. Oryza sativa L. Gene OsLEA 30.

\section{REFERENCES}

ABEDI, T.; PAKNIYAT, H. Antioxidant enzyme changes in response to drought stress in ten cultivars of Oilseed Rape (Brassica napus L.) Czech Journal of Genetics and Plant Breeding, v. 46, n. 1, p. 27-3, 2010.

AEBI, H. Catalase. In: Methods of Enzymatic Analysis (Vol. 3). Verlag Chemie, Weinheim, Florida. 1983.

AEBI, H. Catalase in vitro. Methods Enzymol, v. 105, p. 121-126, 1984. http://dx.doi.org/10.1016/S00766879(84)05016-3

AKINBILE, C. O.; El-LATIF, K. M.; ABDULLAH, R.; YUSOFF, M. S. Rice Production and Water use Efficiency for Self-Sufficiency in Malaysia: A Review. Trends in Applied Sciences Research, v. 6, n. 10, p. 1127-1140, 2011. http://dx.doi.org/10.3923/tasr.2011.1127.1140

BATES, L. S.; WALDREN, R. P.; TEARE, L. D. Rapid determination of free proline in water stress studies. Plant and Soil, v. 39, n. 1, p. 205-207, 1973. http://dx.doi.org/10.1007/BF00018060

CHUTIA, J.; BORAH, S. P. Water stress efffects on leaf growth and chlorophyll content but not the grain yield in traditional rice (Oryza sativa L.) genotypes of Assam, India 1l. Protein and proline status in seedlings under PEG induced water stress. American Journal of Plant Sciences, v. 3, n. 7, p. 971-980, 2012. http://dx.doi.org/10.4236/ajps.2012.37115 
De DATTA, S. K.; MALABUYOC, J. A.; ARAGON, E. L. A Field Screening Technique for Evaluating Rice Germplasm for drought tolerance during the vegetative stage. Field Crops Research, v. 19, n. 2, p. 123-134, 1988. http://dx.doi.org/10.1016/0378-4290(88)90050-0

FAROOQ, M.; WAHID, A.; LEE, D. J.; ITO, O.; SIDDIQUE, K. H. M. Advances in Drought Resistance of Rice. Critical Reviews in Plant Sciences, v. 28, p. 199-217, 2009.

http://dx.doi.org/10.1080/07352680902952173

HENDERSON, S. A., FUKAI, S., LILLEY, J. M., GEORGE, D. L., COOPER, M., WAMALA, M. H.,WATIKI, J. M., VILLARICIENCIO, J. N. CHINYAMAKOBVU, E., UAIENE, R., LUDLOW, M. M. Influence of water stress on leaf death among rice lines:comparison between glasshouse and field. Proceedings of the 7th Australian Agronomy Conference. 1993.

ISLAM, M. R.; XUE, X.; MAO, S.; REN, C.; ENEJI, A. E.; HU, Y. Effects of water-saving superabsorbent polymer on antioxidant enzyme activities and lipid peroxidation in oat (Avena sativa $\mathrm{L}$.) under drought stress. Journal of the Science of Food and Agriculture, v. 91, n. 4, p. 680-686, 2011. http://dx.doi.org/10.1002/jsfa.4234

KADIOGLU, A.; TERZI, R. A dehydration avoidance mechanism: leaf rolling. The Botanical Review, v. 73, n. 4, p. 290-302, 2007. http://dx.doi.org/10.1663/0006-8101(2007)73[290:ADAMLR]2.0.CO;2

KADIOGLU, A.; TERZI, R.; SARUHAN, N.; SAGLAM, A. Current advances in the investigation of leaf rolling caused by biotic and abiotic stress factors. Plant Science, v. 182, p. 42-48, 2012. http://dx.doi.org/10.1016/j.plantsci.2011.01.013

MAFAKHERI, A.; SIOSEMARDEH, A.; BAHRAMNEGAD, B.; STRUIK, P. C.; SOHRABI, Y. Effect of drought stress on yield, proline and chlorophyll contents in three chickpea cultivars. Australian Journal of Crop Science, v. 4, n. 8, p. 580-585, 2010.

MOSTAJERAN, A.; RAHIMI-EICHI, V. Effects of Drought Stress on Growth and Yield of Rice (Oryza sativa L.) Cultivars and Accumulation of Proline and Soluble Sugars in Sheath and Blades of Their Different Ages Leaves. American-Eurasian Journal of Agricultural and Environmental Science, v. 5, n. 2, p. 264-272, 2009.

O'TOOLE, J. C.; CRUZ, R. T. Leaf rolling and traspiration. Plant Science Letters, v. 16, n. 1, p. 111-114, 1979. http://dx.doi.org/10.1016/0304-4211(79)90015-4

PRASAD, P. V. V.; STAGGENBORG, S. A. Impacts of Drought and/or Heat stress on physiological, developmental, growth, and yield processes of crop plants. In Ahuja, L. R.; Reddy, V. R.; Saseendran S. A.; Yu, Q. (Eds.), Response of Crops to Limited Water: Understanding and Modeling water stress effects on plant growth processes: American Society of Agronomy,Inc., Crop Science Society of America, Inc., Soil Science Society of America, Inc. 2008.

WANG, X.; ZHU, H.; JIN, H.; WU, W.; ZHU, J. Genome-scale identification and analysis of LEA genes in rice (Oryza sativa L.). Plant Science, v. 172, p. 414-420, 2007. http://dx.doi.org/10.1016/j.plantsci.2006.10.004

XOCONOSTLE-CAZARES, B.; RAMIREZ-ORTEGA, R. A.; FLORES-ELENES, L.; RUIZ-MEDRANO, R. Drought Tolerance in Crop Plants. American Journal of Plant Physiology, v. 5, P. 241- 256, 2010. http://dx.doi.org/10.3923/ajpp.2010.241.256

XUE, L.; ANJUM, S. A.; WANG, L.; SALEEM, M. F.; LIU, X.; IJAZ, M. F.; BILAL, M. F. Influence of straw mulch on yield, chlorophyll contents, lipid peroxidation and antioxidant enzymes activities of soybean under drought stress. Journal of Food, Agriculture \& Environment, v. 9, n. 2, p. 699-704, 2011. 